\begin{tabular}{|l|l|l|}
\hline \multicolumn{2}{|c|}{ PublisherInfo } \\
\hline \hline PublisherName & $:$ & BioMed Central \\
\hline \hline PublisherLocation & $:$ & London \\
\hline \hline PublisherImprintName & $:$ & BioMed Central \\
\hline \hline
\end{tabular}

\title{
Integrative genomics finds disease genes
}

\begin{tabular}{|l|c|l||}
\hline \multicolumn{2}{|c|}{ ArticleInfo } \\
\hline \hline ArticleID & $:$ & 4677 \\
\hline \hline ArticleDOI & $:$ & $10.1186 /$ gb-spotlight-20030114-01 \\
\hline \hline ArticleCitationID & $:$ & spotlight-20030114-01 \\
\hline \hline ArticleSequenceNumber & $:$ & 29 \\
\hline \hline ArticleCategory & $:$ & Research news \\
\hline ArticleFirstPage & $:$ & 1 \\
\hline \hline ArticleLastPage & $:$ & 2 \\
\hline \hline & & RegistrationDate : 2003-1-14 \\
\hline ArticleHistory & $:$ & OnlineDate \\
\hline \hline ArticleCopyright & $:$ & BioMed Central Ltd2003-14 \\
\hline \hline ArticleGrants & $:$ & \\
\hline \hline ArticleContext & $:$ & 130594411 \\
\hline \hline
\end{tabular}




\section{Jonathan B Weitzman}

Email: jonathanweitzman@hotmail.com

In the Early Edition of the Proceedings of the National Academy of Sciences Mootha et al. describe an integrative genomic approach to discover a gene associated with the human cytochrome c oxidase (COX) deficiency, Leigh syndrome, French Canadian type (LSFC). LSFC is one of five autosomal recessive COX deficiencies; the other four are due to defects in genes encoding COX assembly factors. Mootha et al. combined experimental data from genomic, transcriptome and proteomic studies to identify the gene causing LSFC. They systematically analysed potential genes in the LSFC candidate region that had been narrowed down to a 2 megabase genomic region on chromosome 2p16-21. Neighborhood analysis of large-scale microarray data identified genes that are co-regulated with mitochondrial genes; this was combined with organelle-specific mass spectrometry proteomic data. Integrating these DNA, mRNA and protein-based data led to the identification of a promising candidate gene, $L R P P R C$ (leucine-rich pentatricopeptide repeat-containing protein). Mootha et al. found mutations in $L R P P R C$ in patients with LSFC, validating their integrative genomic approach to disease-gene discovery.

\section{References}

1. Proceedings of the National Academy of Sciences, [http://www.pnas.org]

2. Identification of a gene causing human cytochrome $c$ oxidase deficiency by integrative genomics, [http://www.pnas.org/cgi/doi/10.1073/pnas.242716699]

3. Leigh syndrome, French Canadian type, [http://www.ncbi.nlm.nih.gov/entrez/ dispomim.cgi?id=220111]

4. Cytochrome $c$ oxidase deficiency. 